\title{
Comparison between Properties of Biochar Produced by Traditional and Controlled Pyrolysis
}

\author{
Eman H. El-Gamal ${ }^{1,2}$, Maher Saleh ${ }^{2 *}$, Ibrahim Elsokkary ${ }^{2}$, Mohamed Rashad ${ }^{1}$, Mona M. Abd El-Latif ${ }^{3}$
}

\begin{abstract}
Biochar is usually produced from crop residues (feedstock) by pyrolysis process under controlled conditions in specialized reactors. The characterization of biochar properties produced under field condition is limited. The objective of this study was to compare the physicochemical properties of biochar produced from two feedstocks; sugarcane bagasse feedstock (SCBF) and rice husk feedstock (RHF), under traditional field conditions (primitive) and controlled conditions. The temperature of traditional pyrolysis process was kept around $500{ }^{\circ} \mathrm{C}$. However pyrolysis temperature under controlled conditions was repeated at $450{ }^{\circ} \mathrm{C}$ and $550{ }^{\circ} \mathrm{C}$. In general, the results showed that increasing pyrolysis temperature decreased biochar yield and increased volatile matter, total surface area and total pore volume which were higher in RHBs than in SCBBs, the pHs of both biochars were to the alkaline range, ash and $\mathrm{Si}$ percentages of $\mathrm{RHBs}$ were higher than that of SCBBs. Furthermore, the $C$ percentage which was higher in SCBB than in RHB. The FR-IR spectral showed that the presence of free $\mathrm{OH}$ group and $\mathrm{C}$ $H$ stretch in both feedstocks disappeared in produced biochars under different pyrolysis conditions. The SEM images showed the presence of longitudinal pores in SCBF while SCBB $\left(550^{\circ} \mathrm{C}\right)$ contained longitudinal structure and fewer micropores, while the images of the RHF showed disturbed order of elongated pores which have been changed to developed pores in RHB $\left(550{ }^{\circ} \mathrm{C}\right.$ and traditional). The data of XRD analysis of SCBF indicated the presence of cellulose and disappeared in its three biochars while, XRD data of RHF and RHBs indicate the presence of amorphous silica and quartz. Both biochars produced in the field using traditional pyrolysis unit showed approximately biochar properties as those produced under controlled condition $\left(550^{\circ} \mathrm{C}\right)$.
\end{abstract}

Key words: Feedstock, Sugarcane bagasse, Rice husk, Pyrolysis, Biochar.

\section{INTRODUCTION}

About 30 million tons of agriculture biomass or crop residues in Egypt is produced annually (Gomaa et al., 2011 and El-Haggar et al., 2004). Traditional uses of agricultural residues in Egypt are animal feeding, composting and $50 \%$ of biomass is used as a fuel in low efficiency traditional furnaces or direct combustion in the agricultural field. The traditional furnaces in rare areas are primitive mud stoves which cause air pollution and are extremely energy inefficient (El-Haggar et al., 2004). Due to the wide availability of its raw materials (feedstock), which makes the production of biochar much less expensive, as compared to activated carbon. Biochar is a carbon-rich highly porous material produced from various types of biomass under thermal decomposition and under limited or no supply of oxygen. Recently biochar has received great attention by many researcher because of its promising potentials in many environmental applications, including enhance soil properties, water treatment as a filtration media, and environmental remediation as absorbing and adsorbing agent to reduce organic and inorganic pollutants from wastewater as well as carbon sequestration and mitigate greenhouse gas (GHG) emissions (Novotny et al., 2015, Trakal et al., 2011). The potential uses of biochar as soil improvement by enhancing physicochemical and microbial properties including decrease bulk density, improve soil aggregate stability and water holding capacity in the coarse-textured soil, facilitate drainage in the poorly drained soil, improve soil erosion potential via macroaggregates formation, increase soil $\mathrm{pH}$, cation exchange capacity, base cation percentage, enhance soil fertility, biomass carbon and microbial activity (Burrell et al., 2016, Novotny et al., 2015, Herath et al., 2013, Jien and Wang, 2013).

The thermal process of biochar production is called pyrolysis. There are several types of pyrolysis processes, i.e. slow pyrolysis (carbonization), fast pyrolysis and gasification. During pyrolysis, heating the raw biomass increases its local temperature and consequently its water is evaporated (drying stage), and then pyrolytic volatiles are progressively released (primary pyrolysis stage) from biomass. Variations in the pyrolysis process

\footnotetext{
${ }^{1}$ Land and Water Technologies Department, Arid Lands Cultivation

Research Institute (ALCRI), City of Scientific Research and

Technological Applications (SRTA-City), 21934 New Borg El Arab

City, Alexandria, Egypt.

${ }^{2}$ Department of Soil and Water Science, Faculty of Agriculture,

Alexandria University, El-Shatbi, Alexandria, Egypt.

${ }^{3}$ Fabrication Technology Department, Advanced Technology and

New Materials Research Institute (ATNMRI), City of Scientific Research and

Technological Applications (SRTA- city).

*Corresponding author : Maher.saleh@alex-agr.edu.eg

Received July 20, 2017, Accepted August 11, 2017
} 
and its conditions greatly affect the quality and properties of biochar including temperature and residence time, which are considered the most important parameters. The properties of the final product are also dependent upon the nature of the feedstock. The higher pyrolysis temperature tends to increase the volatile matter content, $\mathrm{pH}$ value, $\mathrm{C} \%$, mineral and ash contents, biochar aromaticity, porosity and specific surface area, and therefore increase the sorptive capacity of biochar (Wu et al., 2012 ; Zhao et al., 2013, Zhang et al., 2015 and Novotny et al., 2015).

The type of feedstock usually affects several biochar's properties such as ash content, the $\mathrm{H} / \mathrm{C}$ ratio, $\mathrm{pH}$, surface area, cation exchange capacity and oxygenrich function groups (Mukome et al., 2013 and Břendová et al., 2012). Thus, biomass pyrolysis generates a complex combinations of products from the individual pyrolysis of cellulose, hemicellulose, lignin and extractives (Novotny et al., 2015). It has been reported that lignin-rich biomass is considered to produce a higher yield with better biochar properties (Lee et al., 2013 and Novotny et al., 2015). Thus, different types of plants produced their specific types of biochar. Biomass with higher cellulose content pyrolyzes faster than biomass with higher lignin content (Gani and Naruse, 2007). The overall pyrolysis stage is completed at temperature around $500{ }^{\circ} \mathrm{C}$ (Novotny et al., 2015). Pyrolysis at relatively high temperature (above $500{ }^{\circ} \mathrm{C}$ ) produced biochar of high aromaticity, relatively low $\mathrm{O} / \mathrm{C}$ atomic ratio. This $\mathrm{O} / \mathrm{C}$ ratio is an important indicator of stability and functionality of biochar (Spokas, 2010). Many researchers studied biochar properties which produced under controlled conditions (temperature and time), while the properties of the traditional biochar which produced under field condition still limited.

Farmers can use the simple methods to produce traditional biochar in the field to improve soil properties, so this study aimed to compare the physical and chemical properties of biochars produced from sugarcane bagasse (SCB) and rice husk (RH) feedstocks under field and controlled thermal conditions.

\section{MATERIALS AND METHODS}

\section{1- Pyrolysis Unit Design:}

A traditional pyrolysis technique was used to produce biochar from agricultural wastes. A prototype of pyrolysis unit was manufactured in a workshop located in New Borg Al-Arab City. The design of pyrolysis unit as showed in Fig. (1), consists of double jacket reactor which made from iron. The height and diameter of the external barrel reactor are 100 and 60 $\mathrm{cm}$ respectively, this barrel has six holes in the bottom the diameter of each is $10 \mathrm{~cm}$ to allow air moving inside and burn the wood to reach the desired temperature. The cover of this barrel has a chimney with $100 \mathrm{~cm}$ in height. The internal barrel has $80 \mathrm{~cm}$ and $40 \mathrm{~cm}$ in height and diameter respectively, its cover has many small holes (0.5 cm diameter) to allow gases to escape away during carbonization process. A stainless steel net inside the reactor is ready to contain the desired amount of feedstock which needed to be converted to biochar.

\section{2- Feedstock and Biochar preparation:}

Sugarcane bagasse feedstock (SCBF) and Rice husk feedstock (RHF) as cellulosic and lignin-cellulosic biomass, respectively, were selected to be used as feedstocks for biochar preparation. SCBF was collected from a variety of local markets located in New Borg AlArab City, Alexandria Governorate. SCBF was washed by tab water, dried in an open field and divided into smaller particle sizes (Fig. 2). RHF was collected from private sector rice mill located in small village called Ezbet Elaw, Sidi Salem, Kafr El-Sheikh Governorate.

The raw material was put in a stainless steel net then inside well-sealed barrel of the pyrolysis unit, and the raw material was burnt under partially absence of oxygen. During this process, the temperature was kept around $500{ }^{\circ} \mathrm{C}$ for 2 for $\mathrm{SCBF}$ and $5 \mathrm{hrs}$ for RHF. The weight of the produced material (biochar) was measured after cooling to $25^{\circ} \mathrm{C}$. Both SCB biochar (SCBB) and $\mathrm{RH}$ biochar (RHB) samples were ground in a mortar and passed through $0.5 \mathrm{~mm}$ sieve. The biochar produced by this process is defined as Traditional (Primitive) Biochar (Fig. 2). Other biochars were produced from SCBF and RHF under controlled conditions in a muffle furnace (VULCANE A-550 model) at two temperatures; 450 and $550{ }^{\circ} \mathrm{C}$ and for the same time periods ( $2 \mathrm{hrs}$ for SCB and $5 \mathrm{hrs}$ for $\mathrm{RH}$ ) which have been used for traditional biochar production (Saleh et al., 2012).

The biochar yield was calculated according to Lynch and Joseph (2010), on air-dry weight basis of the raw material, as follows:

Biochar yield $(\%)=\left(\mathrm{W}_{1} / \mathrm{W}_{0}\right) * 100(1)$,

Where: $\mathrm{W}_{0}$ is the weight of the raw feedstock on an air-dried basis $(\mathrm{g})$, and $\mathrm{W}_{1}$ is the weight of the produced biochar $(\mathrm{g})$.

\section{3- Characterization of Physicochemical properties:}

Some specific physicochemical parameters were determined in feedstocks and biochars as follow:

Structural Constituent: cellulose, hemicellulose and lignin contents in both feedstocks were determined according to the methods described by Van Soest et al., 1991.

Ash content: the ash content was determined by the dry combustion for $1.00 \mathrm{~g}$ of the different feedstock or 
biochar samples at $700{ }^{\circ} \mathrm{C}$ for $12 \mathrm{hrs}$ in an open porcelain crucible (Samsuri et al., 2014). The crucible was cooled in a desiccator until reaching the room temperature, the ash weight was determined. The percentage of the ash content was calculated according to Lynch and Joseph (2010) as follows:

Ash content $(\%)=\left(\mathrm{W}_{\text {ash }} / \mathrm{W}_{\text {sample }}\right) \times 100(2)$,

Where: $\mathrm{W}_{\text {ash }}$ is the weight of ash $(\mathrm{g})$ and $\mathrm{W}_{\text {sample }}$ is the weight of feedstock or biochar $(\mathrm{g})$. hours. After cooling in a desiccator, the sample was reweighed and the moisture content of the biochars was calculated. This process was repeated several times until a constant weight of biochar sample was obtained (Samsuri et al., 2014) as follows:

Moisture content $(\%)=\left(\mathrm{W}_{2}-\mathrm{W}_{3} / \mathrm{W}_{2}-\mathrm{W}_{1}\right) * 100$ (3)

Where: $\mathrm{W}_{1}$ is the weight of crucible $(\mathrm{g}), \mathrm{W}_{2}$ is the initial weight of crucible plus biochar sample $(\mathrm{g}), \mathrm{W}_{3}$ is the final weight of crucible with biochar sample $(\mathrm{g})$.

Moisture content: five grams of biochar were put in a porcelain crucible and dried in an oven at $80^{\circ} \mathrm{C}$ for 24

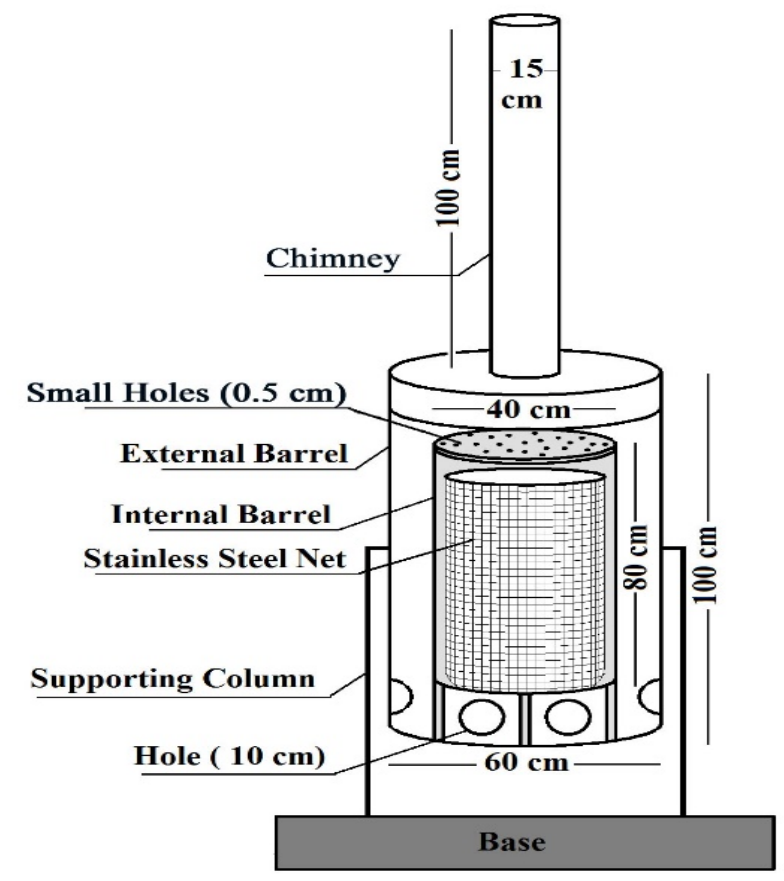

Fig. 1. Schematic layout of Prototype of Pyrolysis Unit (Front View)
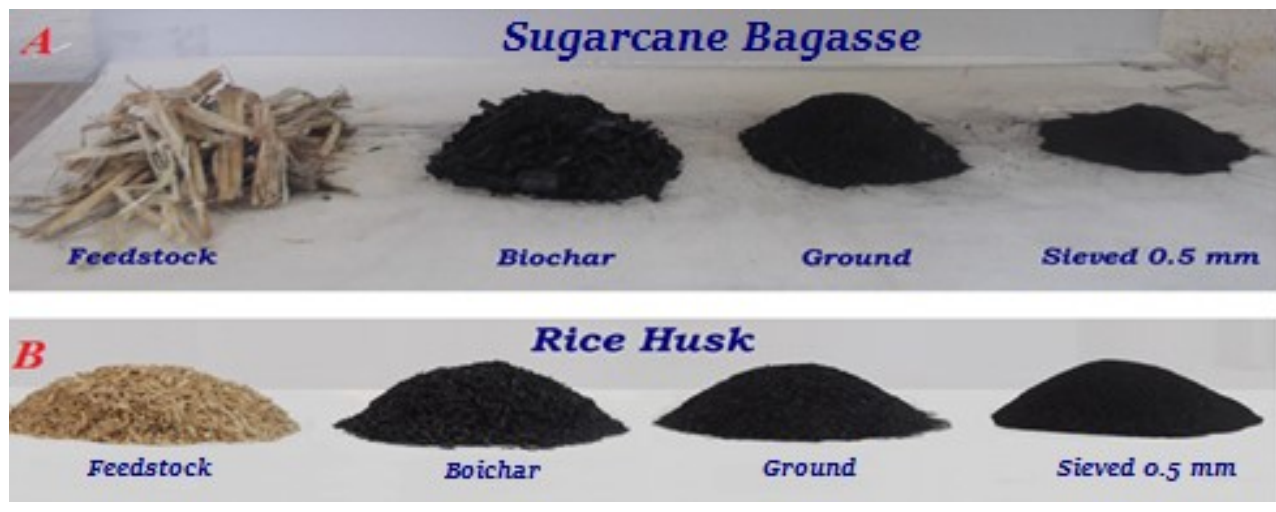

Fig. 2. Photographs of biochar produced from (A) Sugarcane Bagasse and (B) Rice Husk 
Surface area: the surface area of biochar was measured using $\mathrm{N}_{2}$ sorption isotherms run on BElSORP-mini II and the Brunauer-Emmett-Teller (BET) measured at 273 ${ }^{\circ} \mathrm{K}$ and interpreted using Grand Canonical Monte Carlo simulations of the non-local density functional theory for micropore-enclosed $(<1.5 \mathrm{~nm})$ surfaces.

Scanning Electron Microscopy (SEM): the morphology of the feedstocks and biochars was studied using a JEOL, Model JSM 6360 LA, Japan. In order to avoid the build-up of local electrical charges, the samples were coated with gold using sputtering coater (model: S150B, Edwards High Vacuum Ltd., UK) before investigation.

Fourier transform infrared (FTIR) spectral analysis: this technique was used to study the compositional properties for biomass and biochar determining the functional groups by scanning these samples with infrared rays in the range $400-4000 \mathrm{~cm}^{-1}$ using SHEMATZU infra-red spectrophotometer model FT/IR5300, JASCO Corporation, Japan.

X-ray diffraction (XRD) diffractometry: it was studied to characterize the crystalline structure and identify the main components in the feedstocks and biochars. XRD was performed on the ground samples using a SHIMADZU XRD-7000, X-ray diffractometer with $\mathrm{Cu}-\mathrm{K} \alpha$ radiation opeted at $30 \mathrm{kV}$ and $30 \mathrm{~mA}$ and scanning from 5 to $90^{\circ} 2 \theta$, using a step size of $0.02^{\circ} 2 \theta$ and at a scanning rate of $4 \% \mathrm{~min}$.

pH: one gram biochar was mixed with $100 \mathrm{ml}$ of deionized water. The obtained suspension heated to about $90{ }^{\circ} \mathrm{C}$ with stirring for $20 \mathrm{~min}$. After cooling to room temperature, the $\mathrm{pH}$ of the suspension was measured by pH-meter model, Accumet Research AR50 (Masulili et al., 2010).

Cation exchange capacity (CEC): a modified ammonium- acetate compulsory displacement method (Sumner and Miller, 1996) was used for measuring the CEC as described by Gaskin et al. (2008). $1.0 \mathrm{~g}$ biochar sample was placed in a $50-\mathrm{ml}$ polyethylene centrifuge tube, leached five times by deionized water, then $20 \mathrm{ml}$ of deionized water were added and shaken using an orbital shaker for $5 \mathrm{~min}$. at $180 \mathrm{rpm}$. This process was repeated five times, then the sample was centrifuged and the suspension was saved for further analysis. Ten $\mathrm{ml}$ of neutral Na- acetate $(1 \mathrm{M})$ was added to the sample with shaking for $10 \mathrm{~min}$. This process was repeated three times. The Na-biochar samples were then washed three times by ethanol, the adsorbed $\mathrm{Na}^{+}$ions were displaced by $30 \mathrm{ml}$ of one normal neutral $\mathrm{NH}_{4}$ - acetate for three times in $100 \mathrm{ml}$ volumetric flask and the concentration of $\mathrm{Na}^{+}$was measured by flame photometer.
Elemental analysis: carbon, hydrogen, nitrogen, and sulphur contents of the feedstocks and biochars were determined by using a CHNS Elemental Analyzer (Vario type, El, elemental analyzer). The oxygen content was obtained by subtracting $[100 \%-(\mathrm{C} \%+\mathrm{H}$ $\%$ )] according to El-Sherif and Fathy, (2011). Total nutrients in the feedstocks and biochars were extracted by adding $10 \mathrm{~mL}$ concentrated $\mathrm{HNO}_{3}$ : $\mathrm{HCl}$ (1:3) "Aqua Regia" to the ash (dry combustion of $1.00 \mathrm{~g}$ of biomaterial at $500{ }^{\circ} \mathrm{C}$ for $6 \mathrm{hrs}$ ). After cooling to room temperature, the digested solution was filtered into a $100-\mathrm{mL}$ volumetric flask and brought to volume with de-ionized water. Total concentrations of $\mathrm{Cu}, \mathrm{Fe}, \mathrm{Mn}$, and $\mathrm{Zn}$ were measured in the extract of the dry-ashing by atomic absorption spectrophotometer, model, Varian, Spectra (AA-220). The concentration of total $P$ in this extract was measured by ammonium paramolybdatevanadate method and the color intensity was measured at 420-nm wavelength by T80 UV/VIS Spectrophotometer, PG Instruments Ltd (Olsen and Sommers, 1982). The concentration of $\mathrm{K}$ and $\mathrm{Na}$, in the same extract, were measured by flame photometer, FP902, PG Instruments. The concentration of dissolved organic carbon (DOC) was determined in the filtrate (0.45 $\mu \mathrm{m}$ membrane filter) of $5 \% \mathrm{~W} / \mathrm{V}$ solid/distilled water extract (after shaken the suspension for $24 \mathrm{hrs}$ at $150 \mathrm{rpm}$ and centrifuged in at $5000 \mathrm{rpm}$ for $20 \mathrm{~min}$ ) by using the TOC analyzer, multi-N/C UV3100, Analytikjena product, Germany (Wong et al., 2007). The electric conductivity (EC) was measured in the DOC extraction using a conductivity meter WTW inoLab Cond 720 (WTW GmbH, Weilheim, Germany).

\section{RERSULTS AND DISCUSSION}

\section{1- Feed stock Properties}

The Structure constituents for both SCBF and RHF were illustrated in Table 1. The contents of cellulose and hemicellulose as well as moisture content of SCBF were higher than that of RHF. It has been reported that the typical amount of cellulose in biomass ranges from 40 to $60 \%$ and that of hemicellulose from 20 to $40 \%$ (Zhang et al., 2010). On the other hand, RHF had higher contents of lignin and ash than that of SCBF. It is common that lignin accounts a range from 18 to $40 \%$ of several biomass materials (Novotny et al., 2015). These variations can be attributed to the presence of different organic constituents in the two feedstocks that indicated higher lignin in RHF which is amorphous and hydrophobic polymer with high molecular weight and numerous functional groups of aromatic substructure (Lee et al., 2013). 
Table 1. The selected physiochemical properties of the (SCB) and (RH) air-dried feedstock

\begin{tabular}{|c|c|c|c|}
\hline \multirow{2}{*}{ Parameter } & & \multicolumn{2}{|c|}{ Feedstock } \\
\hline & & SCB & RH \\
\hline \multicolumn{4}{|c|}{ Chemical Parameter } \\
\hline $\mathrm{pH}$ & & 3.39 & 6.76 \\
\hline $\mathrm{EC}$ & $\mathrm{dS} / \mathrm{m}$ & 0.97 & 0.61 \\
\hline DOC & $\%$ & 6.00 & 0.42 \\
\hline \multicolumn{4}{|c|}{ Total Elemental Analysis } \\
\hline $\mathrm{C}$ & $\%$ & 42.82 & 33.76 \\
\hline $\mathrm{N}$ & $\%$ & 0.50 & 0.48 \\
\hline $\mathrm{H}$ & $\%$ & 1.54 & 1.79 \\
\hline $\mathrm{O}$ & $\%$ & 53.90 & 52.35 \\
\hline $\mathrm{S}$ & $\%$ & 0.42 & 0.17 \\
\hline $\mathrm{H} / \mathrm{C}$ & atomic ratio & 0.430 & 0.636 \\
\hline $\mathrm{O} / \mathrm{C}$ & atomic ratio & 0.944 & 1.163 \\
\hline$(\mathrm{O}+\mathrm{N}) / \mathrm{C}$ & atomic ratio & 0.954 & 1.175 \\
\hline $\mathrm{Si}$ & $\%$ & 1.74 & 12.1 \\
\hline $\mathrm{P}$ & $\%$ & 0.10 & 0.02 \\
\hline K & $\%$ & 1.03 & 0.26 \\
\hline $\mathrm{Na}$ & $\%$ & 0.19 & 0.12 \\
\hline $\mathrm{Fe}$ & $\mathrm{mg} / \mathrm{kg}$ & 253.81 & 273.63 \\
\hline $\mathrm{Mn}$ & $\mathrm{mg} / \mathrm{kg}$ & 12.53 & 93.53 \\
\hline $\mathrm{Zn}$ & $\mathrm{mg} / \mathrm{kg}$ & 171.35 & 173.95 \\
\hline $\mathrm{Cu}$ & $\mathrm{mg} / \mathrm{kg}$ & 17.83 & 9.07 \\
\hline
\end{tabular}

* DOC dissolved organic carbon

The $\%$ of cellulose, hemicellulose and lignin for both biomaterials are similar with those in the previous studies (Ludueña et al., 2011, Rezende et al., 2011, Kumar et al., 2013, Guilherme et al., 2015, Wang et al., 2016).

Where, cellulose and hemicellulose are consisting of simple sugar monomers they decompose at a temperature lower than $450{ }^{\circ} \mathrm{C}$. These two compounds have lower molecular weight than lignin and easily released as pyrolytic vapors (Lee et al., 2013), while lignin is very resistant to thermal degradation.

The higher ash content in RHF than in SCBF indicates the presence of higher element contents in RHF than in SCBF. Several studies reported that SCBF contains low ash content as compared with that of RHF (Saleh et al., 2013, and Jindo et al., 2014), this could be due to the higher amount of Si in RHF (Table 1). Si is a major component in the chemical structure of rice (Jindo et al., 2014). However, the higher amount of DOC for SCBF may be attributed to the high content of cellulose and hemicellulose (Bottino et al., 2016).
As shown in Table 1 the results indicated lower $\mathrm{pH}$ value for SCBF than that of RHF. This indicated the presence of more acidic groups in SCBF compared with RHF.

It is clear from Table 1 that there is no marked variation in the electrical conductivity (EC) value of both SCB and RH feedstocks even it seems relatively higher in SCB than in RH. Thus there are slight variations in the percentages of $\mathrm{N}, \mathrm{H}$, and $\mathrm{O}$ between both feedstocks (Table 1). On the other hand, the percentages of $\mathrm{C}$ and $\mathrm{S}$ were markedly higher in SCBF than in RHF while that of $\mathrm{Si} \%$ was higher in RHF than in SCBF. The concentration of S, P, K, and Na were relatively higher in SCBF than that in RHF. However, the concentrations of $\mathrm{Fe}$ and $\mathrm{Zn}$ were approximately close, while Mn was markedly higher in RHF than in $\mathrm{SCBF}$ and $\mathrm{Cu}$ was markedly higher in SCBF than in RHF. 


\section{Biochar Properties}

Physical properties: Table 2 shows that the biochar yield of RHBs produced under different pyrolysis condition was higher than that of SCBB. However, it was observed that the yield of both SCBB and RHB was decreased with increasing pyrolysis temperature from 450 to $550{ }^{\circ} \mathrm{C}$, this could be due to thermal decomposition and destructive of reaction of cellulose (Novak et al., 2009, Jindo et al., 2014 and Claoston et al., 2014). It is clear from Table 2 that the yield of traditional biochar of both SCBB and RHB were very close to their yield when produced under a controlled condition at $550{ }^{\circ} \mathrm{C}$ for both biochars.

The percentage of volatile matter released from SCBB were higher than from RHB at different pyrolysis conditions, and increased with increasing pyrolysis temperature from 450 to $550{ }^{\circ} \mathrm{C}$. It is clear that percentage of volatile matter in traditional SCBB was higher than in that of traditional RHB and both two traditional biochars have volatile matter close to those produced at $550{ }^{\circ} \mathrm{C}$ pyrolysis temperature.

It is clear from these data that the type of feedstock had marked effect on the percentage of volatile matter. The percentages of moisture content of $\mathrm{SCBBs}$ were higher in SCBBs than in RHBs and these percentages were approximately very close at the two pyrolysis temperatures $\left(450\right.$ and $550{ }^{\circ} \mathrm{C}$ ) and also with that of traditional biochars of both SCB and RH (Table 2). The moisture content in biochar is related to feedstock rather than to pyrolysis temperature.

Ash percentage in both biochars has increased with increasing pyrolysis temperature from 450 to $550{ }^{\circ} \mathrm{C}$ and this percentage was higher in the RHBs than SCBBs (Table 2).

Table 2. The physiochemical properties of the SCB and RH biochars

\begin{tabular}{|c|c|c|c|c|c|c|c|}
\hline \multirow{2}{*}{\multicolumn{2}{|c|}{ Parameter }} & \multicolumn{3}{|c|}{ SCBB } & \multicolumn{3}{|c|}{ RHB } \\
\hline & & Traditional & $450^{\circ} \mathrm{C}$ & $550{ }^{\circ} \mathrm{C}$ & Traditional & $450^{\circ} \mathrm{C}$ & $550^{\circ} \mathrm{C}$ \\
\hline \multicolumn{8}{|l|}{ Physical Parameters } \\
\hline$\overline{\text { Biochar yield }}$ & $\%$ & 32.06 & 41.71 & 34.93 & 40.31 & 46.17 & 39.92 \\
\hline Volatile matter & $\%$ & 67.94 & 58.29 & 65.07 & 59.69 & 53.83 & 60.08 \\
\hline Ash & $\%$ & 19.07 & 17.69 & 21.43 & 40.19 & 43.43 & 49.51 \\
\hline Moisture content & $\%$ & 9.32 & 9.51 & 8.80 & 5.03 & 4.89 & 5.15 \\
\hline Total Surface Area & $\mathrm{m}^{2} / \mathrm{g}$ & 185.60 & 107.87 & 124.11 & 154.67 & 98.01 & 212.99 \\
\hline Total Pore Volume $\mathrm{p} / \mathrm{p}^{0}$ & $\mathrm{~cm}^{3} / \mathrm{g}$ & 0.11 & 0.06 & 0.08 & 0.10 & 0.07 & 0.12 \\
\hline Mean Pore Diameter & $\mathrm{nm}$ & 2.31 & 2.28 & 2.41 & 2.55 & 2.66 & 2.31 \\
\hline \multicolumn{8}{|l|}{ Chemical Parameters } \\
\hline $\mathrm{pH}$ & & 8.63 & 8.40 & 9.00 & 8.85 & 8.33 & 9.44 \\
\hline $\mathrm{EC}$ & $\mathrm{dS} / \mathrm{m}$ & 0.70 & 0.63 & 0.62 & 0.46 & 0.58 & 0.45 \\
\hline CEC & $\mathrm{meq} / 100 \mathrm{gm}$ & 31.89 & 33.85 & 33.00 & 26.15 & 24.85 & 27.13 \\
\hline DOC & $\%$ & 0.02 & 0.03 & 0.02 & 0.05 & 0.03 & 0.02 \\
\hline \multicolumn{8}{|l|}{ Total Elements Analysis } \\
\hline $\mathrm{N}$ & $\%$ & 0.76 & 0.86 & 0.82 & 0.68 & 0.58 & 0.85 \\
\hline $\mathrm{C}$ & $\%$ & 51.37 & 54.84 & 67.92 & 38.50 & 41.31 & 42.82 \\
\hline $\mathrm{H}$ & $\%$ & 0.80 & 0.46 & 0.64 & 0.47 & 0.58 & 0.45 \\
\hline $\mathrm{O}$ & $\%$ & 43.88 & 40.78 & 26.70 & 33.73 & 28.61 & 23.10 \\
\hline $\mathrm{S}$ & $\%$ & 0.74 & 0.70 & 0.36 & 0.16 & 0.38 & 0.13 \\
\hline $\mathrm{H} / \mathrm{C}$ & atomic ratio & 0.19 & 0.10 & 0.11 & 0.15 & 0.17 & 0.13 \\
\hline $\mathrm{O} / \mathrm{C}$ & atomic ratio & 0.64 & 0.56 & 0.30 & 0.66 & 0.52 & 0.41 \\
\hline$(\mathrm{O}+\mathrm{N}) / \mathrm{C}$ & atomic ratio & 0.65 & 0.57 & 0.31 & 0.67 & 0.53 & 0.42 \\
\hline $\mathrm{Si}$ & $\%$ & 3.96 & 3.92 & 4.74 & 27.30 & 29.50 & 33.63 \\
\hline $\mathrm{P}$ & $\%$ & 0.29 & 0.27 & 0.21 & 0.01 & 0.02 & 0.02 \\
\hline $\mathrm{K}$ & $\%$ & 0.50 & 0.44 & 0.37 & 0.54 & 0.61 & 0.63 \\
\hline $\mathrm{Na}$ & $\%$ & 0.39 & 0.34 & 0.43 & 0.29 & 0.28 & 0.29 \\
\hline $\mathrm{Fe}$ & $\mathrm{mg} / \mathrm{kg}$ & 1914 & 2344 & 2688 & 968 & 246 & 322 \\
\hline $\mathrm{Mn}$ & $\mathrm{mg} / \mathrm{kg}$ & 54.35 & 67.64 & 54.74 & 57.85 & 55.33 & 54.61 \\
\hline $\mathrm{Zn}$ & $\mathrm{mg} / \mathrm{kg}$ & 158.10 & 146.31 & 127.85 & 143.51 & 131.16 & 140.49 \\
\hline $\mathrm{Cu}$ & $\mathrm{mg} / \mathrm{kg}$ & 12.87 & 15.06 & 14.07 & 10.21 & 8.49 & 9.71 \\
\hline
\end{tabular}


The high percentage of ash content in RHB at different pyrolysis temperature, relative to that of SCBB is related to chemical composition of rice (Wu et al., 2012 and Jindo et al., 2014).

Table 2 shows wide variations in the values of total surface area due to both the type of feedstock and the pyrolysis temperature. Low pyrolysis temperature (450 ${ }^{\circ} \mathrm{C}$ ) produced the least total surface area of both SCBB and RHB relative to that of high temperature $\left(550^{\circ} \mathrm{C}\right)$ or to that of traditional biochar. Similar trend can be observed with respect to total pore volume (Table 2), low pyrolysis temperature $\left(450{ }^{\circ} \mathrm{C}\right)$ produced the least total pore volume for both SCBB and RHB which were approximately very close. Similarly, traditional SCBB and RHB have approximately close values of total pore volume values. The increase of total surface area of biochar with increasing pyrolysis temperature is attributed to the formation of micropores (GarcíaJaramilloa et al., 2015). Claoston et al. (2014) found that the surface area of the rice husk biochar increased with increasing temperature and this could be due to the removed of volatile material and resulting in increasing micropore volume (Ahmad et al., 2012).

Fourier Transform-Infrared (FT-IR) spectra: As presented in Fig. 3, FTIR data of SCB feedstock and its biochars were less different from those of RH with respect to the intensity. The peaks around 3813.4 and $3786.39 \mathrm{~cm}^{-1}$ indicates the existence of free hydroxyl functional group (O-H stretching) in SCBF and RHF, due to the chemically absorbed water and also due to the surface hydroxyl groups (Saleh et al., 2013). These peaks could be disappeared in the different biochars, except for RHB produced at $450{ }^{\circ} \mathrm{C}$ which appeared at

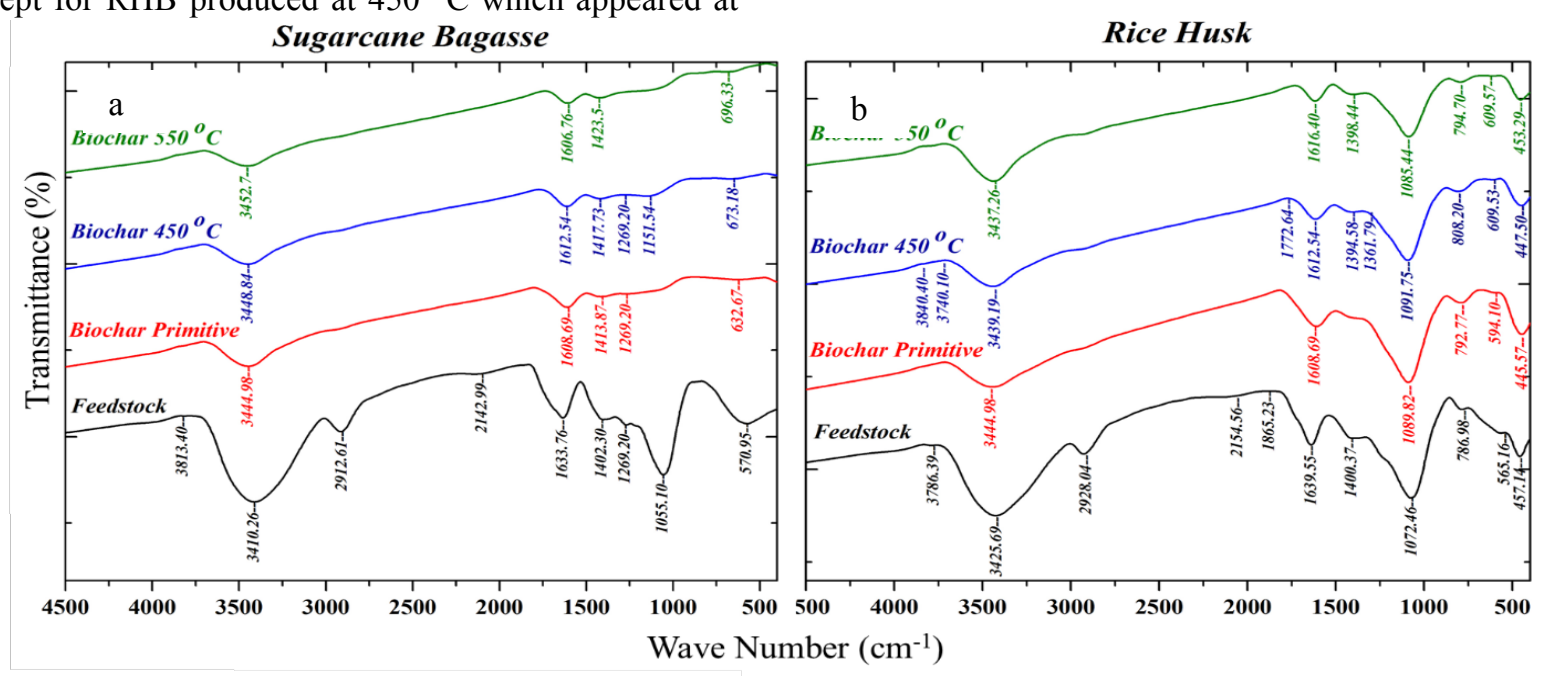

Fig. 3. FT-IR Spectra of Feedstocks and biochars of Sugarcane Bagasse (a) and Rice Husk (b) feedstock
3740.10 and $3840.40 \mathrm{~cm}^{-1}$. The FTIR spectra of the feedstocks and biochars for SCB and RH, indicated that the band in the range 3410.26 to $3452.7 \mathrm{~cm}^{-1}$ is depicting the stretching of hydroxyl group and H-bonds groups from alcohols, phenols, and organic acids (Jindo et al., 2014). In addition, silanol group (Si-OH) was found in rice husk. These bands were more intense in the feedstock than in the biochar, which is produced under different pyrolysis conditions (Daffalla et al., 2010). Throughout the increasing pyrolysis temperature, the stretching band of hydrogen-bonded hydroxyl groups started to diminish (Fig. 3). This was may be due to higher mass loss during thermal decomposition and gas evolution (Claoston et al., 2014).

The peaks at 2921.61 and $2928.04 \mathrm{~cm}^{-1}$ in SCBF and RHF, respectively, is assigned to saturated $\mathrm{C}-\mathrm{H}$ stretching vibration (aliphatic $\mathrm{C}-\mathrm{H}$ ) which indicates the presence of alkane functional group. This has been observed for the two feedstocks and disappeared in the biochars as a result of dehydration of cellulosic and ligneous components (Zhao et al., 2013 and Guilherme et al., 2015) and dehydrogenation of methylene groups, which yielded increasingly condensed structures $\left(\mathrm{R}-\mathrm{CH}_{2}-\mathrm{R} \rightarrow \mathrm{R}=\mathrm{CH}-\mathrm{R} \rightarrow \mathrm{R}=\mathrm{C}=\mathrm{R}\right)$, controlled biochar recalcitrance (Harvey et al., 2012 and Zhao et al., 2013). Similar observation has been found in the band at $1055.10 \mathrm{~cm}^{-1}$ in SCBF only (alcohol C-O stretch and aliphatic amines $\mathrm{C}-\mathrm{N}$ ). Due to the high content of silicon in rice husk (Mahmoud et al., 2011), the different functional groups in which silicon exists (e.g., siloxane $\mathrm{Si}-\mathrm{O}-\mathrm{Si}$ and silanol $\mathrm{Si}-\mathrm{OH}$ ) were clearly observed in FT-IR spectra (Fig. 3-b). 
The FT-IR spectra showed typical bonds of $\mathrm{Si}-\mathrm{O}-\mathrm{Si}$ stretching at $1072.46-1091.75 \mathrm{~cm}^{-1}$ and the bands at $\mathrm{Si}-$ $\mathrm{O}$ at $786.98-808.20 \mathrm{~cm}^{-1}$ and $445.57-457.14 \mathrm{~cm}^{-1}$ for $\mathrm{RH}$ and RHB. Similar results were obtained by Saleh et al. (2013). The $\mathrm{N}-\mathrm{H}$ bend and $\mathrm{C}=\mathrm{C}$ stretching vibrations between $1606.76-1639.55 \mathrm{~cm}^{-1}$ in SCB and $\mathrm{RH}$ are indicative of amines, alkenes and aromatic functional groups, respectively (Claoston1 et al., 2014 and Daffalla et al., 2010). The presence of amide groups in both SCBB and RHB, are indicated by the high $\mathrm{N}$ concentrations (Table 2) (Claoston1 et al., 2014). The intensity of $\mathrm{C}=\mathrm{O}$ stretching of aromatic rings (1606.79$1639.55 \mathrm{~cm}^{-1}$ ) was higher in the feedstocks than biochars and decreased with temperature rise in biochars and seemed similar in SCB and RH feedstocks (Zhao et al., 2013). Claoston et al. (2014) mentioned that peaks around $1700 \mathrm{~cm}^{-1}$ indicate the existence of holocellulose and lignin, while the peak around $1400 \mathrm{~cm}^{-1}$ may be attributed to the aromatic $\mathrm{CH}$ and carboxyl-carbonate structures and silanol groups. The silanol groups are in the form of silicon dioxide structure $(-\mathrm{Si}-\mathrm{O}-\mathrm{Si}-\mathrm{OH})$. This structure is similar to the silanol groups of silicic acid (Srivastava et al. 2006). Aromatic $\mathrm{C}=\mathrm{C}$ ring stretching were observed between 1400 and $1600 \mathrm{~cm}^{-1}$ and the peaks at $1260 \mathrm{~cm}^{-1}$, corresponding to aromatic CO- stretching, were observed for all biochars. Aromatic $\mathrm{C}=\mathrm{C}$ peaks are an indication of benzene-like rings. These aromatic molecules have extra stability caused by the nature of their structure. The bands around 565.16 and 609.57 indicate the presence of alkyl halides (C-Br stretch), in contrast another study showed that it may be due to the stretching variation of both inorganic compounds such as $\mathrm{KCl}$ and $\mathrm{CaCl}_{2}$ (Claoston et al. 2014).

Comparing the surface chemistry of feedstock and biochars produced at traditional, $450{ }^{\circ} \mathrm{C}$, and $550{ }^{\circ} \mathrm{C}$ showed that raw feedstocks and biochars had similar surface functional groups and in spite of that some of these peaks had disappeared. The disappearance of these peaks was an indication of decreases in water and aliphatic compounds. Also, a new peak around $1400 \mathrm{~cm}^{-1}$, corresponding to aromatic $\mathrm{C}=\mathrm{C}$ stretching, appeared on the biochar surface. This indicates an increase in the aromaticity during pyrolysis as temperature increased

SEM micrographs: The images showed a significant changes to the surface morphology of the both biomaterials (SCB and $\mathrm{RH}$ ) before and after pyrolysis process. The SEM images showing fibrous channels in both biochars. The biochars' structure consisted of a highly complex network of pores. The SEM images of SCBF showed differences as compared with those of different SCB biochars which produced at different conditions of pyrolysis process (traditional, $450{ }^{\circ} \mathrm{C}$ and $550{ }^{\circ} \mathrm{C}$ ). At 2000 magnification the presence of longitudinal pores in SCBF is originated from the vascular structure of this biomass (Fig. 4). On the other hand, the micrograph of the external surface of traditional SCBB (X 2000) is full of cavities of porous structures. These pores are of different size and shapes and different than those of SCBF (Fig.4). These pores can be devolved from the thermal decomposition of cellulose and hemicellulose and left the cell walls which contain large proportions of lignin (Novotny et al., 2015). The mean pore diameter of SCBBs are 2.31, 2.28 and $2.41 \mathrm{~nm}$ for traditional, $450{ }^{\circ} \mathrm{C}$ and $550{ }^{\circ} \mathrm{C}$, respectively. SEM micrograph of SCBB produced at $550{ }^{\circ} \mathrm{C}$ and at magnification of 2000 contained longitudinal structure. The surface of this biochar contains slit-shaped pores containing particulates of different size. The wall thickness of traditional SCBB was less than biochar produced at $450{ }^{\circ} \mathrm{C}$ and higher than that produced at $550{ }^{\circ} \mathrm{C}$ which became very thin due to the effect of high temperature. It means that thermal degradation of cellulose and hemicellulose as the pyrolysis temperature increases.

The SEM images of RHF showed, at 2000 magnification, disturbed order of elongated pores. On the other hand, RHB produced at traditional, $450{ }^{\circ} \mathrm{C}$ and $550{ }^{\circ} \mathrm{C}$ showed developed pores (X 2000) as a result of thermal decomposition of $\mathrm{RH}$ structure and converted it to small particles. It seems that the walls of pores contain materials that disturb its regular order. Increasing pyrolysis temperature to $550{ }^{\circ} \mathrm{C}$ produced RHB of well-developed pores which are observed clearly at 2000 magnification. The SEM micrograph of traditional and $550{ }^{\circ} \mathrm{C}$ RHB exhibited a variety of shapes and sizes of micropores and macropores. Similar observations have been reported by Daffalla et al., 2013. The regular pattern of pores was more observed in SCBB produced at traditional ${ }^{\circ} \mathrm{C}$ and in RHB produced at $550{ }^{\circ} \mathrm{C}$. This variation could be due to the difference in the specific structure of raw SCB and RH feedstocks. Thus, by increasing pyrolysis temperature (from $450{ }^{\circ} \mathrm{C}$ $-550{ }^{\circ} \mathrm{C}$ ), the structure of RHB became more ordered than SCBB and the pore diameter decreased with increasing pyrolysis temperature of RHB as follows: $2.66 \mathrm{~nm}\left(450{ }^{\circ} \mathrm{C}\right), 2.41 \mathrm{~nm}$ (traditional) and $2.31 \mathrm{~nm}$ $\left(550{ }^{\circ} \mathrm{C}\right)$. Claoston et al. (2014) suggested that with increasing pyrolysis temperature, the number of micropores of $\mathrm{RH}$ biochar had decreased and that of macropores has increased. They also reported that the properly arranged pore structure possess high BET surface area and adsorptive capacity. 
$\mathrm{RH}$

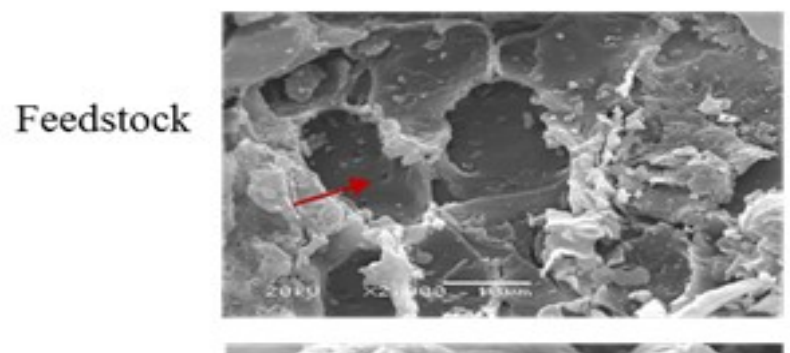

Primitive

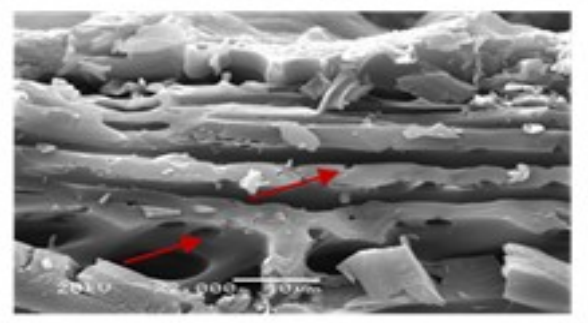

$450{ }^{\circ} \mathrm{C}$

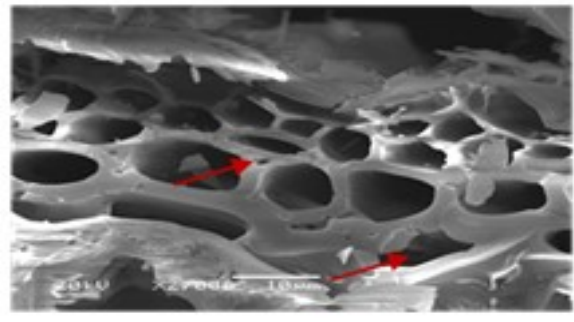

$550{ }^{\circ} \mathrm{C}$

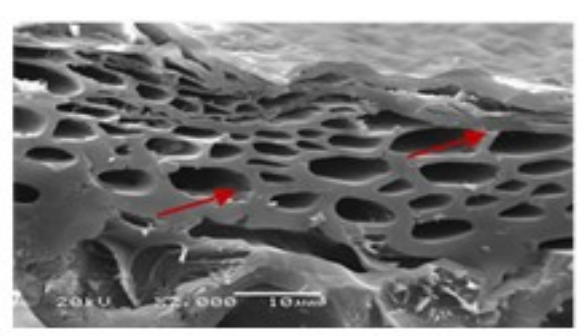

SCB
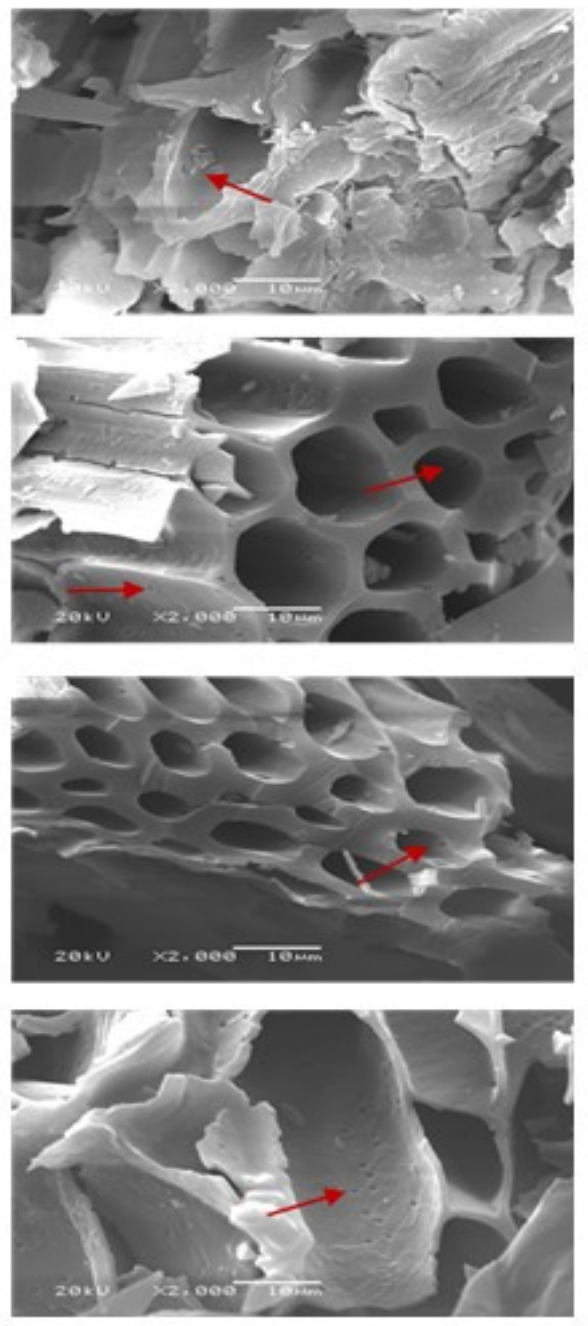

Fig 4. The SEM images of RH and SCB feedstocks and different biochars (traditional "primitive", $450{ }^{\circ} \mathrm{C}$, and $550{ }^{\circ} \mathrm{C}$ ) representing the changes and voids formation on the surface of biochar samples

X-Ray Diffraction: The X-ray patterns for SCB feedstock and biochars (Fig. 5) showed a remarkable differences among both of them which indicate that phase transformation has been taken. The peaks at $2 \theta$ between $22^{\circ}$ and $28^{\circ}$ indicate the presence of cellulose which has a broad peak. The intense broad peak of cellulose in feedstock has been disappeared as a result of the thermal treatments. This may be due to the thermal degradation of cellulose in biochars. According to Govindarajan and Jayalakshmi (2011) carbon compounds present in the SCB are considerably removed at high temperature. The other peak at $2 \theta \sim$ $26^{\circ}$, which indicates the presence of silica, is more sharp in biochars especially in traditional one. This may be due to the recrystallization of amorphous silica with increasing temperatures (Tantawy et al., e2014).

The results of X-ray diffraction patterns of $\mathrm{RH}$ feedstock and its derived biochars made at (traditional, and of $450{ }^{\circ} \mathrm{C}$, and $550{ }^{\circ} \mathrm{C}$ ) did not show well-defined peaks. In all biomaterials, a peak is observed within the ranges from $15^{\circ}$ to $30^{\circ}$, indicating disordered structure. XRD analysis of the feedstock and biochars confirmed the presence of amorphous silica as indicated by the heap at $2 \theta \sim 22.5^{\circ}$ idue to amorphous silica and quartz amorphous silica, which is a major constituent of these biomaterials, can be present in form of disordered cristobalite $\left(\mathrm{SiO}_{2}\right)$ (Singh et al., 2008 and Srivastava et al., 2006). 


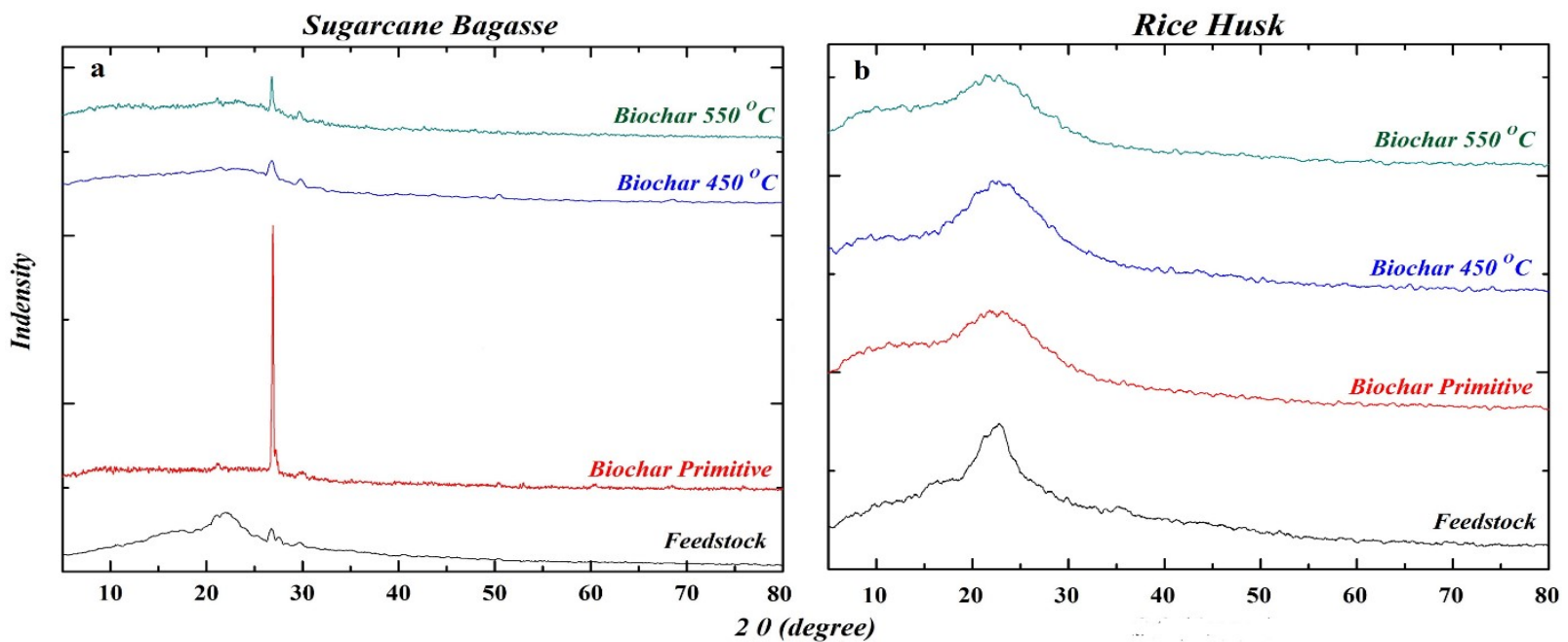

Fig. 5. XRD of feedstock and biochar produced at different pyrolysis conditions for Sugarcane Bagasse (a) and Rice Husk (b)

Chemical properties: Table 2 shows that, on the average, the $\mathrm{pH}$ value of SCBBs lower than in the RHBs. The value of $\mathrm{pH}$ of both biochars has increased with increasing pyrolysis temperature and both are with in alkaline range. The $\mathrm{pH}$ values of traditional SCBB and traditional RHB were higher than those produced at $450{ }^{\circ} \mathrm{C}$ and lower those that produced at $550{ }^{\circ} \mathrm{C}$ for both biochars. This result could be due to the high ash content in RHF than in SCBF (Novake et al., 2009 and García-Jaramilloa et al., 2015). Increase the $\mathrm{pH}$ value of biochars due to increasing temperature could be attributed to the concentration of non-pyrolyzed inorganic elements (Novake et al., 2009 and Jindo et al., 2014) and also to decomposition of organic matrix and consequently of minerals such as alkali metals (ash) which are main cause of high pH (Ahmad et al., 2012; Tsai et al., 2012; and Al-Wabel et al., 2013 and Claoston et al., 2014). García-Jaramilloa et al. (2015) reported that high pyrolysis temperature reduces the amount of carboxylic group, and the acidic groups and de-protonated to the conjugate basic nature, resulting in more alkaline $\mathrm{pH}$ of the biochar. On the average, the EC values of all biochars were less than unity and represent non-saline biochars. In general, EC was higher, in SCBBs than in the RHBs. With respect to the levels of $\mathrm{DOC}$, there were no marked variations in the concentration of DOC in both biochars (Table 2). Due to low DOC content, indicate that biochar degraded very slowly in soil.

Table 2 shows that, on the average, SCBBs has higher values of CEC than those of RHBs. The pyrolysis temperature (traditional, $450{ }^{\circ} \mathrm{C}$ and $550{ }^{\circ} \mathrm{C}$ ) did not affect markedly the value of CEC of SCBBs which decreased in biochar produced at traditional than at 450 ${ }^{\circ} \mathrm{C}$ and $550{ }^{\circ} \mathrm{C}$. While $\mathrm{CEC}$ of $\mathrm{RHB}$ produced at traditional and $550{ }^{\circ} \mathrm{C}$ was increased as compared to $450{ }^{\circ} \mathrm{C}$ with a value of relative $5.23 \%$ and $9.17 \%$, respectively. However, Claoston et al. (2014) obtained different and opposite results with RHB who found that cation exchange capacity of RHB was decreased with increasing temperature.

Elemental Analysis: The N content in SCBB did not change markedly due to increasing of pyrolysis temperature (from 450 and $550{ }^{\circ} \mathrm{C}$ ) but increased in the case of RHB. The $\mathrm{N}$ percentage in traditional biochars was higher in SCBB $(0.76 \%)$ than in RHB $(0.68 \%)$ and both were lower than $\mathrm{N}$ percentage in both biochars produced at $550{ }^{\circ} \mathrm{C}$. However, high pyrolysis temperature $\left(550{ }^{\circ} \mathrm{C}\right)$ produced biochars rich in $\mathrm{N}$ contents in both SCBB and RHB. On the other hand, increasing pyrolysis temperature from 450 to $550{ }^{\circ} \mathrm{C}$ decreased $\mathrm{H}$ percentage in RHB, while there was an increase in $\mathrm{H}$ content in SCBB with increasing temperature from $0.46 \%$ to $0.64 \%$ at 450 and $550{ }^{\circ} \mathrm{C}$, respectively. As shown in Table 2. The percentage of $\mathrm{H}$ in traditional RHB $(0.47 \%)$ was lower than that of SCBB $(0.80 \%)$. The $\mathrm{C}$ contents in SCBB increased from $54.84 \%$ to $67.92 \%$ with temperature increase from 450 to $550{ }^{\circ} \mathrm{C}$ while, this trend was less observed for RHB. Traditional biochar of SCB contained higher C $(51.37 \%)$ than that of RHB (38.50\%). However, these two traditional $\mathrm{SCBB}$ and $\mathrm{RHB}$ contained the lowest $\mathrm{C} \%$ as compared with $\mathrm{C}$ contents in both biochars of produced under controlled conditions at 450 and $550^{\circ} \mathrm{C}$ (Table 2 ). It was observed an opposite trend in the $\mathrm{O}$ contents relative to $\mathrm{C}$ contents in both biochars. 
Jindo et al. (2014) found that an increase in pyrolysis temperature led to in a large loss of $\mathrm{O}$ and $\mathrm{H}$ as compared to that of $\mathrm{C}$ which increases. The highest $\mathrm{H} / \mathrm{C}$ atomic ratio was found in traditional SCBB (0.19) higher than those produced under controlled conditions at $450{ }^{\circ} \mathrm{C}(0.10)$ and $550{ }^{\circ} \mathrm{C}(0.11)$. This ratio was lower in traditional RHB (0.15) than in that of RHB of $450^{\circ} \mathrm{C}$ (0.17) and was higher than that of RHB of $550{ }^{\circ} \mathrm{C}$ (0.13). These data showed that increasing pyrolysis temperature (from $450{ }^{\circ} \mathrm{C}$ to $550^{\circ} \mathrm{C}$ ) had increased $\mathrm{H} / \mathrm{C}$ atomic ratio of SCBB (Table 2). This may be due to the loss of easily degradable $\mathrm{C}$ compounds such as volatile matter (Jindo et al., 2014). The $\mathrm{O} / \mathrm{C}$ atomic ratio of traditional biochar had the highest ratio for SCB (0.64) and for RH (0.66) as compared with those of SCBB (0.56 and 0.30$)$ and of RHB (0.52 and 0.41) which are produced at controlled pyrolysis conditions of $450{ }^{\circ} \mathrm{C}$ and $550 \mathrm{C}$, respectively. Also, the low atomic ratio of $\mathrm{O} / \mathrm{C}$ at the highest pyrolysis temperature can be attributed to a structural arrangement of the aromatic rings (Spokas et al., 2010) which form very stable graphite-like structure (Wu et al., 2012). And thus, the atomic ratio $(\mathrm{O}+\mathrm{N}) / \mathrm{C}$ has the same trend for both biochars produced under different pyrolysis conditions. The occurrence of high ratio of both $\mathrm{H} / \mathrm{C}, \mathrm{O} / \mathrm{C}$ and $(\mathrm{O}+\mathrm{N}) / \mathrm{C}$ in traditional $\mathrm{SCBB}$ and $\mathrm{RHB}$ and relative to those produced under controlled conditions. These data indicate that these ratios are more interactive with polar compounds. This also indicates that traditional SCBB and RHB and those produced at low temperature (450 ${ }^{\circ} \mathrm{C}$ ) are most polar at lower temperature than high temperature (Novake et al., 2009).

The percentage of $\mathrm{S}$ in SCBBs was almost higher than in RHBs (Table 2) and this percentage decreased with the increase of pyrolysis temperature from $450{ }^{\circ} \mathrm{C}$ to $550{ }^{\circ} \mathrm{C}$ in both biochars, while that of traditional SCBB was the highest $(0.74 \%)$. Silicon ( $\mathrm{Si}$ ) contents in biochars produced from SCBF at different condition were extremely lower than those produce from RHF (Table 2). The highest Si percentage, in SCBB or RHB, was produced at high pyrolysis temperature $\left(550{ }^{\circ} \mathrm{C}\right)$. The Si percentage in traditional biochars were markedly close to those produced at $450{ }^{\circ} \mathrm{C}$ for both biochars (Table 2). These data confirm positive relation between ash content and $\mathrm{Si}$ content in biochars and that both properties are influenced by pyrolysis temperature since both are increased markedly with increasing pyrolysis temperature especially with respect RHB rather than SCBB (Table 2).

The $\mathrm{P}$ percentage in SCBB decreased with increasing pyrolysis temperature from 450 to $550{ }^{\circ} \mathrm{C}$ while, those of RHBs were approximately close at the two temperatures $\left(450\right.$ and $\left.550{ }^{\circ} \mathrm{C}\right)$. Table 2 showed higher P percentage in traditional SCBB than in RHB and also in those of controlled SCBB and RHB. On the other hand, $\mathrm{K}$ contents decreased in SCBB with increasing temperature while it increased in RHB with increasing temperature. Traditional SCB and $\mathrm{RH}$ biochars contained approximately close $\mathrm{K}$ percentage. The percentage of $\mathrm{Na}$ in SCBB increased with increasing temperature while this percentage was approximately close in $\mathrm{RH}$ biochar. The traditional SCBB contained more $\mathrm{Na}(0.39 \%)$ than traditional RHB $(0.29 \%)$.

Fe percentage of SCBB and RHB increased with increasing pyrolysis temperature, and they were higher in SCBB than in RHB produced under different pyrolysis conditions. However traditional RHB contained higher level of $\mathrm{Fe}$ than in those produced at $450{ }^{\circ} \mathrm{C}$ and $550{ }^{\circ} \mathrm{C}$. On the other hand the content of Mn was higher value in SCBB at $450{ }^{\circ} \mathrm{C}$ than at $550^{\circ} \mathrm{C}$. The contents of $\mathrm{Mn}$ in RHB produced at these two temperatures were very close. The traditional SCBB and RHB contained approximately close Mn contents ( 54.35 and $57.85 \mathrm{mg} / \mathrm{Kg}$, respectively). The content of $\mathrm{Zn}$ in SCBB decreased with increasing temperature and was higher at $450{ }^{\circ} \mathrm{C}$ than at $550{ }^{\circ} \mathrm{C}$ while the opposite was recorded for RHB which increased from 131.2 to 140.5 $\mathrm{mg} / \mathrm{Kg}$, at 450 and $550{ }^{\circ} \mathrm{C}$, respectively. Traditional SCBB contained higher $\mathrm{Zn}$ than that of RHB. The lowest contents of micronutrients was $\mathrm{Cu}$ which showed no remarkable variations due to increase of pyrolysis temperature in both SCBBs and RHBs. It is clear that the percentage of $\mathrm{Cu}$ contents was higher in SCBBs than in RHBs which produced under different conditions. The nutrients in feedstocks ( $\mathrm{P}, \mathrm{K}, \mathrm{S}, \mathrm{Na}$ and $\mathrm{Fe}$ ) were concentrated in the biochar and were higher in the biochars produced at traditional and/or $550^{\circ} \mathrm{C}$.

\section{CONCLUSION}

The variation and heterogeneous in biochar properties based on the pyrolysis conditions and biomass type. The biochar produced in the field from air-dried feedstock using traditional pyrolysis unit under partially absence of the oxygen showed approximately biochar yield (from SCB or RH feedstocks) as those produced under controlled condition $\left(550{ }^{\circ} \mathrm{C}\right)$. In general, the physical properties (ash, moisture content, total pore volume and mean pore diameters) were approximately close of those SCB and RH biochars produced under controlled condition. Furthermore, $\mathrm{pH}$, EC, DOC, CEC, N and C content were approximately close in traditional biochar of SCB and RH with those biochars produced under controlled conditions. However, $\mathrm{O}$ content, $\mathrm{H} / \mathrm{C}$ ratio, $\mathrm{O} / \mathrm{C}$ ratio and $(\mathrm{O}+\mathrm{N}) / \mathrm{C}$ were higher in traditional biochar than in biochars of SCB and RH produced under controlled condition. 
In general, the effect of pyrolysis conditions on biochar properties in this study followed the trend 450 ${ }^{\circ} \mathrm{C}>$ traditional $>550{ }^{\circ} \mathrm{C}$. In general, depending on feedstock, traditional biochars have positive impact as nutrient sources as well as sequester $\mathrm{C}$.

These results confirm the reliability of producing traditional biochar using pyrolysis unit in the field rather than producing under controlled conditions.

\section{REFERENCES}

Ahmad, M., S. S. Lee, X. Dou, D. Mohan, J. K. Sung, J. E. Yang and Y. S. Ok, 2012. Effects of pyrolysis temperature on soybean stover- and peanut shell-derived biochar properties and TCE adsorption in water. Bioresource Technology. 118(5): 36-44.

Al-Wabel, M. I., A. Al-Omran, A. H. El-Naggar, M. Nadeem and A. R.A. Usman, 2013. Pyrolysis temperature induced changes in characteristics and chemical composition of biochar produced from conocarpus wastes. Bioresource Technology 131: 374-379.

Bottino, F.,M. B. Cunha-Santino, and I. B. Jr., 2016. Cellulose activity and dissolved organic carbon release from lignocellulose macrophyte-derived in four trophic conditions.Brazilian journal of microbiology, 47: 352358.

Břendová, K., P. Tlustoš, J. Száková and J. Habart, 2012. Biochar Properties from Different Materials of Plant Origin. Eur. Chem. Bull., 1 (12): 535-539.

Burrell, L. D., F. Zehetner, N. Rampazzo, B. Wimmer, G. Soja, 2016. Long-term effects of biochar on soil physical properties. Geoderma 282: 96-102.

Claoston, N., A. Samsuri, M. A. Husni, and M. M. Amran, 2014. Effects of Pyrolysis Temperature on the Physicochemical Properties of Empty Fruit Bunch and Rice Husk Biochars. Waste Management \& Research, 32(4): 331-339.

Daffalla, S. B., H. Mukhtar and M. S. Shaharun, 2010. Characterization of Adsorbent Developed from Rice Husk: Effect of Surface Functional Group on Phenol Adsorption. Journal of Applied Sciences, 10: 1060-1067.

Daffalla, S. B., H. Mukhtar and M. S. Shaharun, 2013. Removal of Phenol from Aqueous Solutions Using Rice Husk Ash. Casp J Appl Sci Res, 2:36-49.

El- Sherif, I. Y. and N. A.Fathy, 2011. Equilibrium and Kinetic Study of Cd (II) and Ni (II) Ions Removal by Semi-Carbonized $/ \mathrm{H}_{3} \mathrm{PO}_{4}$ Cotton Stalks. Electronic Journal of Environment, Agricultural and food Chemistry, 10 (8): 2744-2758.

El-Haggar S. M., G. Mounir, and L. Gennaro, 2004. Agricultural waste as an energy source in developing countries, a case study in Egypt on the utilization of agricultural waste through complexes. International Centre for Science and High Technology (ICS).United Nations Industrial Development organization (UNODO): 1-10.
Gani, A. and I. Naruse, 2007. Effect of cellulose and lignin content on pyrolysis and combustion characteristics for several types of biomass. Renewable Energy. 32: 649661.

García-Jaramilloa, M. L., Coxa, H. E. Knicker, J. Cornejoa, K. A. Spokas and M. C. Hermosín, 2015. Characterization and selection of biochar for an efficient retention of tricyclazole in a flooded alluvial paddy soil. Journal of Hazardous Materials 286: 581-588.

Gaskin, J. W., C. Steiner, K. Harris, K. C. Das, and B. Bibens, 2008. Effect of Low- Temperature Pyrolysis Conditions on Biochar for Agricultural Use. American Society of Agricultural and Biological Engineers ISSN 0001-2351, 51(6): 2061-2069.

Gomaa, H. A., P. Steele and Y. A. Hamdy, 2011. Charcoal Industries Egypt. Food and Agriculture Organization of the United Nations Regional Office for the Near East, Cairo, Egypt.

Govindarajan, D. and G. Jayalakshmi, 2011. XRD, FTIR and Microstructure Studies of Calcined Sugarcane Baggase Ash. Advanced in Applied Science Research, 2(3): 544549 .

Guilherme, A. A., P. V. F. Dantas, E. S. Santos, F. A. N. Fernandes, G. R. Macedo, 2015. Evaluation of Composition, Characterization and Enzymatic Hydrolysis of Pretreated Sugar Cane Bagasse. Braz. J. Chem. Eng., 32(1): $23-33$.

Harvey, R. O., B. E. Herbert, L. J. Kuo, P. Louchouarn, 2012. Generalized two-dimensional perturbation correlation infrared spectroscopy reveals mechanisms for the development of surface charge and recalcitrance in plantderived biochars. Environ. Sci. Technol., 46: 1064110650.

Herath, H. M. S. K., M. Camps-Arbestain, M. Hedley, 213. Effect of biochar on soil physical properties in two contrasting soils: An Alfisol and an Andisol. Geoderma 209-210: 188-197.

Jien, S-H and C-S. Wang, 2013. Effects of biochar on soil properties and erosion potential in a highly weathered soil. Catena 110: 225-233.

Jindo, K., H. Mizumoto, Y. Sawada, M. A. SanchezMonedero, and T. Sonoki, 2014. Physical and chemical characterization of biochars derived from different agricultural residues. Biogeosciences, 11: 6613-6621.

Kumar, S., P. Sangwan, R. Mor V. Dhankhar and S. Bidra, 2013. Utilization of rice husk and their ash: A review. Research Journal of Chemical and Environmental Sciences 1(2): 126-129.

Lee, Y., J. Park, K. S. Gang, C. Ryu, W. Yang, J-H. Jung, S. Hyun, 2013. Production and Characterization of Biochar from Various Biomass Materials by Slow Pyrolysis. Technical Bulletin Journal - Food and Fertilizer Technology Center, 197: 1-11.

Ludueña, L., D. Fasce, V. A. Alvarez, P. M. Stefani, 2011. Nanocellulose from rice husk following alkaline treatment to remove silica. BioResources 6 (2): 1440-1453. 
Lynch J. and S. Joseph, 2010. Guidelines for the Development and Testing of Pyrolysis Plants to Produce Biochar. Ver. $1.1,7$.

Mahmoud, A. H., M. E. Saleh and A. A. Abdel-Salam. 2011. Effect of Rice Husk Biochar on Cadmium Immobilization in Soil and Uptake by Wheat Plant Grown on Lacustrine Soil. Alex. J. Agric. Res., 56 (2): 117-125.

Masulili, A., W. H. Utomo, and S. MS, 2010. Rice Husk Biochar for Rice Based Cropping System in Acid Soil 1. The Characteristics of Rice Husk Biochar and Its Influence on the Properties of Acid Sulfate Soils and Rice Growth in West Kalimantan, Indonesia. Journal of Agricultural Science, 2(No. 1):39:47.

Mukome, F. N. D., X. Zhang, L. C. R. Silva, J. Six, and S. J. Parikh, 2013. Use of Chemical and Physical Characteristics to Investigate Trends in Biochar Feedstocks. J. Agric. Food Chem., 61:2196-2204.

Novak, J. M., I. Lima, B. Xing, J. W. Gaskin, C. Steiner, K.C. Das, M. Ahmedna, D. Rehrah, D. W. Watts, W. J. Busscher and H. Schomberg, 2009. Characterization of designer biochar produced at different temperatures and their effects on a loamy sand. Annals of Environmental Science, 3: 195-206.

Novotny, E. H., C. M. B. de Freitas Maia, M. T. de M. Carvalho, and B. E. Madari, 2015. Biochar: Pyrogenic Carbon for Agricultural Use - A Critical Review. R. Bras. Ci. Solo, 39:321-344

Olsen, S. R. and L. E. sommers, 1982. Phosphorus. pp 403430, in: AL.Page, R.H.Miller and D.R.Keeny, eds. Methods of soil analysis, part 2. Chemical and microbiological properties. Agronomy Manograph no.9. $2^{\text {nd }}$ Eds. ASA and SSSA, Madison. WI.

Rezende, C. A., M. A. de Lima, P. Maziero, E. R. de Azevedo, W. Garcia and I. Polikarpov, 2011. Chemical and morphological characterization of sugarcane bagasse submitted to a delignification process for enhanced enzymatic digestibility. Biotechnology for Biofuels 4 (54): $1-18$.

Saleh, M. E., A. H. Mahmoud, and M. Rashad, 2012. Peanut Biochar as a Stable Adsorbent for Removing $\mathrm{NH}_{4}-\mathrm{N}$ from Wastewater: A Preliminary Study. Advances in Environmental Biology, 6(7): 2170-2176.

Saleh, M. E., A. H. Mahmoud, and M. Rashad, 2013. Biochar Usage as a Cost-Effective Bio-Sorbent for Removing $\mathrm{NH}_{4}-\mathrm{N}$ from Wastewater. Global Climate Change, Biodiversity and Sustainability: Challenges and Opportunities - an international conference focused on the Arab MENA region and EuroMed. 15-18 April 2013 Alexandria, Egypt.

Samsuri A.W., F. Sadegh-Zadeh, and B.J. Seh-Bardan 2014. Characterization of biochars produced from oil palm and rice husks and their adsorption capacities for heavy metals. Int. J. Environ. Sci. Technol. 11: 967-976.

Singh, D., R. Kumar, A. Kumar and K. N. Rai, 2008. Synthesis and characterization of rice husk silica, silicacarbon composite and $\mathrm{H}_{3} \mathrm{PO}_{4}$ activated silica. Cerâmica, vol, 54, pp 203-212.
Spokas, K. A., 2010. Review of the stability of biochar in soils: predictability of O:C molar ratios. Carbon Manage. 1: 289-303.

Srivastava, V. C., I. D. Mall, I. M. Mishra, 2006. Characterization of mesoporous rice husk ash (RHA) and adsorption kinetics of metal ions from aqueous solution onto RHA. Journal of Hazardous Materials B134: 257267.

Sumner, M. E., and W. P. Miller. 1996. Cation exchange capacity and exchange coefficients, pp. 1201-1229. In D. L. Sparks, A. L. Page, and P. A. Helmke, editors, Methods of Soil Analysis. Part 3, Chemical Methods. Soil Science Society of America, Madison, Wisconsin, USA.

Tantawy, M. A., A. M. El-Roudi and A. A. Salem. 2014. Utilization of bagasse ash as supplementary cementitious material. International Journal of Engineering Research \& Technology 3 (7): 1342-1348.

Trakal, L., M. Komárek, J. Száková, V. Zemanová, P. Tlustoš, 2011. Biochar application to metal-contaminated soil: Evaluating of $\mathrm{Cd}, \mathrm{Cu}, \mathrm{Pb}$ and $\mathrm{Zn}$ sorption behavior using single- and multi-element sorption experiment. Plant Soil Environ., 57 (8): 372-380.

Tsai, W.T., S.C. Liu, H.R. Chen, Y. M. Chang, Y.L. Tsai, 2012. Textural and chemical properties of swine-manurederived biochar pertinent to its potential use as a soil amendment. Chemosphere 89, 198-203.

Van Soest, P.J., Robertson, J. B., and Lewis, B.A., 1991. Methods for dietary fibre, neutral detergent fibre and nonstarch polysaccharides in relation to animal nutrition. $\mathrm{J}$ Dairy Sci., 74 (10): 3583-3597.

Wang, Z., J. Li, J. P. Barford, K. Hellgradt and G. McKay, 2016. A comparison of chemical treatment methods for the preparation of rice husk cellulosic fibers. International Journal of Environmental \& Agriculture Research 2(1): 67-77.

Wong, J. W. C., K. L. Li, L. X. Zhou, and A. Selvam, 2007. The sorption of $\mathrm{Cd}$ and $\mathrm{Zn}$ by different soils in the presence of dissolved organic matter from sludge. Geoderma 137: 310-317.

Wu, W., M. Yang, Q. Feng, K. McGrouther, H. Wang, H. Lu and Y. Chen, 2012. Chemical characterization of rice straw-derived biochar for soil amendment. Biomass and bioenergy 47: 268-276.

Zhang L, C. Xu and P. Champagne, 2010. Overview of recent advances in thermo-chemical conversion of biomass. Energy Conversion and Management, 51: 969-982.

Zhang, J., J. Liu and R. Liu, 2015. Effects of pyrolysis temperature and heating time on biochar obtained from the pyrolysis of straw and lignosulfonate. Bioresource Technology 176: 288-291.

Zhao, L., X. Cao, O. Maŝek., A. Zimmerman, 2013. Heterogeneity of biochar properties as a function of feedstock sources and production temperatures. Journal of Hazardous Materials, 256-257: 1-9. 


\section{الملخص العربي}

\section{مقارنة بين خصائص الفحم الحيوي المنتج تحت ظروف التحطم الحرارى التقليدي والمتحكم فيه}

إيمان حسن الجمل، ماهر السيد صالح، إبر اهيم حسين السكري، محمد رشاد عبد الفتاح، مني محمود عبد اللطيف

OH RHB وأظهرت نتائج تحليل FT-IR وجود مجموعة الحرة ومجاميع C-H المشبعة في كل من RHF و SCBF و التي اختفت في الفحم الحيوي المنتج تحت ظروف التحطم الحراري المختلفة. كما أظهرت صور الميكرسكوب الإلكتروني SEM وجود المسام الطولية في المادة الخام لمصاصة القصب(SCBF) بينما بحتوي الفحم الحيوي له له على بنية طولية وعدد أقلل من المسام الدقيقة و كانت أكثر وضوحاً عند درجة حرارة .00 مُ م، في حين أظهرت صور RHF تغير فى نظام المسام الطولية حيث تغيرت إلى مسام أكثر تطوراً في RHB سواء عند التحكم فى درجة الحرارة •00 مْ أوفى الظروف التقليدية. وأثنارت بيانات تحليل XRD للمادة الخام لمصاصة القصب إلى وجود السليلوز والذي اختفى تماماً في الفحم الحيوي المنتج تحت الظروف المختلفة في حين نشير بيانات XRD للسرسة سواء للمادة الخام أوالفحم المنتج تحت الظروف المختلفة إلى وجود السيليكا غير المتبلورة و الكوارتز. عموماً أظهرت النتائج أن خصائص الفحم الحيوي المنتج في الحقل ولى تحت الظروف التقليدية بإستخدام وحدة التحطم الحراري البدائية لا تختلف كثير أ عن خصائص الفحم الحيوي المنتج تحت الظروف المتحكم فيها (000 درجة مئوية).
عادة ما يتم دراسة خصائص الفحم الحيوي الناتج من عملية التحطم الحراري لمخلفات المحاصيل الزارعية تحت ظروف متحكم فيها في أفران ذات طابع خاص يتيح القدرة

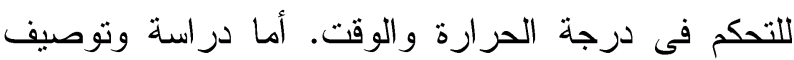
خصائص الفحم الحيوي الناتج تحت ظروف الحقل التقليدية فهى محدودة ولا يمكن الإعتماد عليها فى التوصيف الدقيق للفحم المنتج. لذلك فإن الهدف من هذه الدراسة هو مقارنة

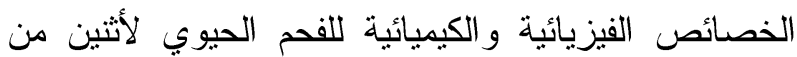

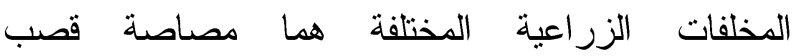
السكر(SCBF) وغلاف حبة الأرز ("السرسة” (RHF)) المنتج تحت الظروف الحقلية التقليدية و الظروف المتحكم فيها (درجات حرارة الإنحلال الحراري .0؛ و .00 مْم).

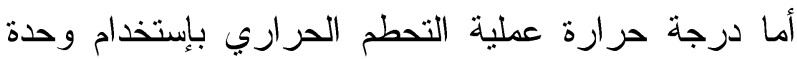

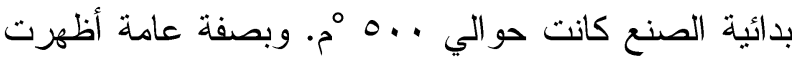

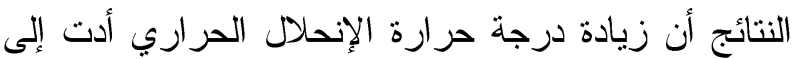
انخفاض نسبة الفحم الناتج وزيادة نسبة المواد المنطايرة ومساحة السطح الكلية وحجم المسام الكلي التي كانت أعلى لى لئ في السرسة (RHB) عن مصاصة القصب (SCBB) المنتج تحت الظروف المختلفة، وكانت قيمة pH في كلاهما في المدي القلوي، ونسبة الرماد والسيليكون أعلى في RHB عن SCBB، أما نسبة كC كانت أعلى في SCBB عن 